\title{
Hypopharyngeal Cancer TNM Finding v7
}

National Cancer Institute

\section{Source}

National Cancer Institute. Hypopharyngeal Cancer TNM Finding v7. NCI Thesaurus. Code C89026.

A finding about one or more characteristics of hypopharyngeal cancer, following the rules of the TNM AJCC V7 classification system. 